\title{
Pollen Allergens of some Road Trees, Shrubs and Herbs in Alexandria, Egypt
}

\author{
Wafaa K Taia* \\ Alexandria University, Faculty of Science, Botany Department, Egypt
}

\begin{abstract}
Sixteen different wild herbs, shrubs and planted road trees pollen grains subjected in this study. The pollen morphology has been examined, described and photographed by SEM, as well as their mineral and protein contents have been investigated. The results showed that pollinosis is not due to special element or protein contents inside the pollen taxa. Protein type is more important than protein concentration. As well as, allergy is not restricted to trees, shrubs or herbs but it depends on the amount of pollen grains in the air and combination between several factors as pollen grain density, air pollution and humidity which rehydrates the pollen to excrete its contents. This work recommends the organization in planting the road trees and not over planting the gardens and parks, as well as choosing the most appropriate taxa that can absorb pollutants. Plant diversity is more important to minimize poillinosis and ensure better urban wildlife.
\end{abstract}

KEYWORDS: Allergy; Air pollution; Aeropalynology; Element contents; Pollen; Road tree

\section{INTRODUCTION}

Recently, within the past few decades, allergic diseases have developed from being rather rare conditions into pandemic health problem. Air pollution by pollen grains and fungal spores considered from the major causes of allergy all over the world. Plants pollinated by air, anemophillous plants, considered from the most important pollen allergens which comprise approximately $10-18 \%$ of all flowering plants (Songnuan, 2013). These pollens considered as major risk factor for both seasonal allergic rhinitis and asthma. Whereas indoor allergens, mostly caused by fungal spores, considered a risk factor for perennial rhinitis (Bousquet et al., 2008). Although both fungal spores and pollen grains considered from the main causes of pollenosis, but peoples suffering from allergy varied considerably depending on the geographic location of the study population and the type of vegetation growing in that area. Climatic changes have its effect on the intensity of pollen seasons which in turn air pollution and contribute the increased numbers of respiratory allergy and asthma D'Amato et al. [1]; Fukuoka [2].

The pollen grains, which are the male sex gametes and carried by air to reach the stigma during pollination period, have specific wall with three main layers Saad [3]. The innermost layer, enclosing the cytoplasm, is the intine which composed of cellulose and pectin. While the outermost layer, which is more resistant layer, composed of sporopollenin. The exine layer surrounds the whole pollen, except few places for germination called apertures, responsible for the protection of the pollen grain. Allergenic proteins, starch, fats and nanovesicles beside other small components such as adenosine are usually located within the pollen protoplast and readily released during the rehydration process, may play a specific role in the course of allergic diseases Prado et al. [4]; Grote et al.
Quick Response Code:

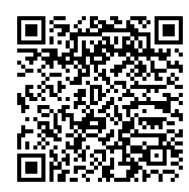

Address for correspondence: Wafaa K Taia, Alexandria University, Faculty of Science, Botany Department, Egypt

Received: February 05, $2020 \quad$ Published: February 20, 2020

How to cite this article: Wafaa KT. Pollen Allergens of some Road Trees, Shrubs and Herbs in Alexandria, Egypt. 2020 - 2(1) OAJBS.ID.000143. DOI: 10.38125/OAJBS.000143 
[5]; Emilson et al. [6] on their studies on birch pollen allergens, in the anhydrous state of the pollen, the allergens are located within the pollen cytoplasm in close proximity to ribosome-rich areas. Upon rehydration, birch pollen allergens are released through the apertures and subsequently found on the entire pollen surface causing hay fever and other allergic symptoms. Allergenic pollen is produced by a number of trees, grasses and weeds found in the road of Alexandria (Egypt). Exposure to such pollen grains can result in the release of pollen-related asthma and allergenic conditions such as allergic rhinitis (pollenosis or hay fever) Geiner et al. [7]. These naturally growing plants, beside those cultivated ones increase the amount of pollen in the air and in turn cause adverse health effects, some people consider pollen as an air pollutant. In response to the environmental changes and global warming on the vegetation and pollen production, there is a need for detailed pollen calendar in each city and-related health impact information and to choose the road trees very carefully to lessen the probability of air pollution by pollen grains Osborne [8]; Asam et al. [9]. Not only so, but also, we need to investigate the chemical and protein constituents in the chosen trees to minimize the probability of allergenic pollen grains in the air as an aid in the treatment of pollen asthma.

In this work, pollen grains of sixteen widely distributed herbs, shrubs, beside planted road trees are examined and measured by light microscope, then photographed by SEM. As well as the element compositions and protein contents of these pollen grains have been estimated to investigate the allergenic constituents in these plants.

\section{MATERIALS AND METHODS}

Table 1: The taxonomic status of the studied species and their life form and span.

\begin{tabular}{|c|c|c|c|c|c|c|}
\hline No. & Order & Family & Genus & Species & Life form & Life span \\
\hline 1 & Utricales & Moraceae & Urica & Urens L. & Herb & Annual \\
\hline 2 & Caryophyllales & Chenopodiaceae & Chenopodium & Album L. & Herb & Annual \\
\hline 3 & Rosales & Caesalpinacese & Delonix & Regia (Bojer) Raf. & Tree Evergreen & Perennial \\
\hline 4 & & & Cassia & Javanica L. & Tree Diciduous & Perennial \\
\hline 5 & & Mimosaceae & Acacia & Tortilis & Tree Diciduous & Perennial \\
\hline 6 & Malvales & Malvaceae & Malvaviscus & Arboreus L. & Shrub Evergreen & Perennial \\
\hline 7 & Geraniales & Euphorbiaceae & Croton & Cotinifolia L. & Tree Deciduous & Perennial \\
\hline 8 & Violales & Tamaricaceae & Tamarix & Nilotica (Ehrenb.) Bge & Tree Evergreen & Perennial \\
\hline 9 & Gentianales & Apocynaceae & Carissa & Macrocarpa (Echlr.) A.Dr. & Shrub Evergreen & Perennial \\
\hline 10 & & & Catharanthus & Roseus (L.) G Don & Shrub Evergreen & Perennial \\
\hline 11 & & Asclepiadaceae & Crystostegia & Grandiflora R.Br. & Climber Evergreen & Perennial \\
\hline 12 & Tubiflorae & Bignoniaceae & Jacaranda & Mimosifolia D.Don & Tree Deciduous & Perennial \\
\hline 13 & & & Tecoma & stans (L.) Juss. Ex Kunth & Shrub Evergreen & Perennial \\
\hline 14 & & & Tecomaria & Capensis (Spach Thumb.) & Shrub Evergreen & Perennial \\
\hline 15 & & & Cestrum & Nocturnum L. & Shrub Evergreen & Perennial \\
\hline 16 & & Solanaceae & Datura & Inoxia Mill & Shrub Evergreen & Perennial \\
\hline
\end{tabular}
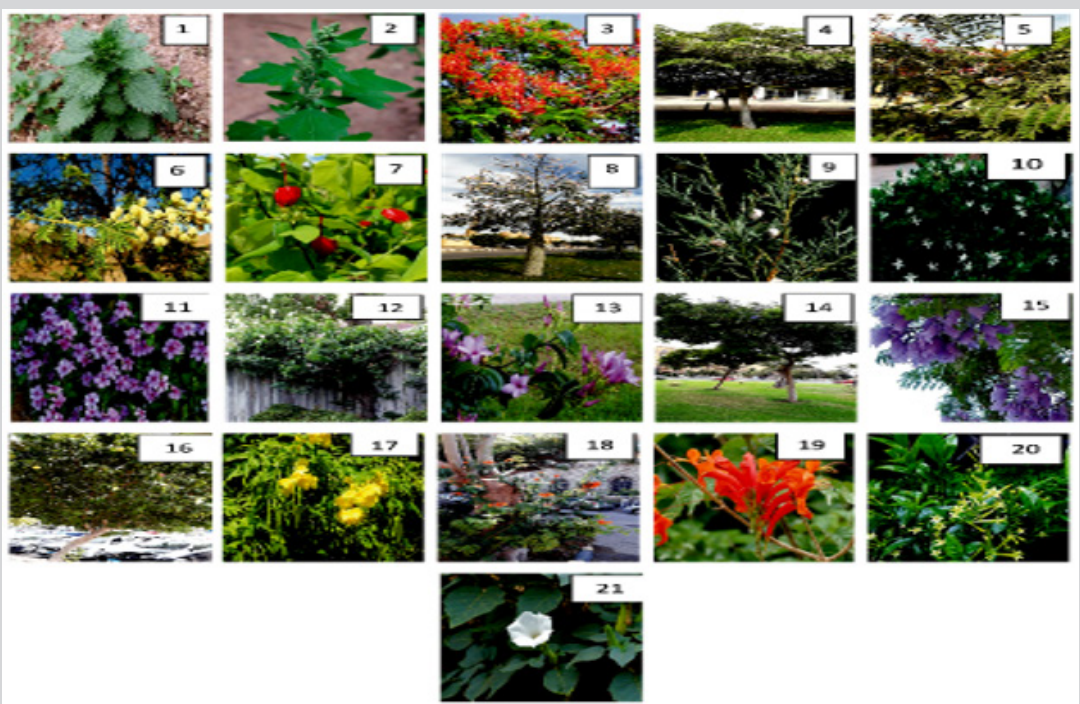

Photo 1-21: 1. Utrica Urens, 2. Chenopodium Album, 3. Delonixregia, $4 \& 5$ Cassia Javanica, 6. Acacia Tortilis, 7. Malvaviscus Arboreus, 8. Croton Cotinifolia, 9. Tamarixnilotica, 10. Carissa Macrocarpa, 11. Catharanthus Roseus 12\&13. Crystostegia Grandiflora 14\&15. Jacaranda Mimosifolia $16 \& 17$. Tecoma Stans 18 \& 19. Tecomariacapensis, 20. Cestrum Nocturnum, 21. Datura Inoxia 
Collected flowers and flower buds of different road streets trees, shrubs and herbs have been subjected in this study during September-October 2019 (beginning of autumn). This collection is from deciduous trees, perennial trees, shrubs and herbs widely found in Alexandria streets, Egypt. The trees were photographed as shown in Photo 1-21, the plants are identified by the aid of Heneidy [10] and their taxonomical position, life forms and span are summarized in Table 1 . The anthers are carefully removed from the flowers immediately after gathering by the aid of Stereomicroscope and stored in glass containers for analysis and further inspection.

Pollen grain pellets have been made of the studied species and subjected to X-ray analysis under $20 \mathrm{kv}$, using JEOL JSL IT200
SEM allocated at Scanning Electron Microscopy Unit, Faculty of Science, Alexandria University, to investigate fifteen main elemental composition, three replicas at each taxa and the mean and standard deviation have been calculated. As well as the non acetolyzed pollens were sputtered onto Aluminum stubs, coated with gold and examined and photographed using JEOL JSL IT 200 SEM. For quantitative protein investigation, the pollen grains were sputtered on glass slides with thin film of egg albumin. The slides were directly stained with bromophenol blue for $2 \mathrm{~min}$., washed in tap water, cleared in xylol, mounted in canada balsam then covered for examination by Olympus light microscope (Mazia et al., 1953). The terminology used here is generally based on that of Faegri [11].

\section{RESULTS}

\section{Pollen Morphology and Protein Contents}

Table 2: Pollen morphological characters and their densities of protein contents of the studied taxa.

\begin{tabular}{|c|c|c|c|c|c|c|c|c|}
\hline No & $\begin{array}{l}\text { Name of } \\
\text { the Taxa }\end{array}$ & Polarity & Shape & Size & Aperture & Ora pos. & Exine Orn. & $\begin{array}{l}\text { Protein } \\
\text { density }\end{array}$ \\
\hline 1 & Utrica Urens & Apolar & Spheroidal & S. & 2-4 pores & Cir. & Granulate & Intense \\
\hline 2 & $\begin{array}{l}\text { Chenopodium } \\
\text { Album }\end{array}$ & Apolar & Spherical & M & pantoporate & Cir. & Granulate & High \\
\hline 3 & Delonix Regia & Isopolar & Oblate & $\mathrm{L}$. & tricolporate & La. & Reticulate & Weak \\
\hline 4 & $\begin{array}{c}\text { Cassia } \\
\text { Javanica }\end{array}$ & Isopolar & Subprolate & M. & tricolporate & Cir. & Reticulate & Moderate \\
\hline 5 & Acacia Tortilis & apolar & Spheroidal & L. & polycolpate & --- & Foveolate & Moderate \\
\hline 6 & $\begin{array}{l}\text { Malviscus } \\
\text { Arboreus }\end{array}$ & apolar & Spherical & V.L. & polyporate & Cir. & Spinulate & Moderate \\
\hline 7 & $\begin{array}{c}\text { Croton } \\
\text { Cotinifolia }\end{array}$ & Apolar & Spheroidal & M. & hexacolpate & --- & Foveolate & High \\
\hline 8 & $\begin{array}{l}\text { Tamarix } \\
\text { Nilotica }\end{array}$ & Isopolar & Prolate & S. & tricolpate & --- & Reticulate & Moderate \\
\hline \multirow[t]{2}{*}{9} & $\begin{array}{c}\text { Carissa } \\
\text { Macrocarpa }\end{array}$ & $\begin{array}{c}\text { Apolar \& } \\
\text { Isopolar }\end{array}$ & I-Spheroidal & $\mathrm{L}$. & tricolpate & --- & Reticulate & High \\
\hline & & & II-Prolate & $\mathrm{L}$. & tetracolpate & Lo. & Reticulate & \\
\hline 10 & $\begin{array}{l}\text { Catharanthus } \\
\text { Roseus }\end{array}$ & Isoplar & Subprolate & M. & tricolporate & Lo. & Reticulate & Moderare \\
\hline 11 & $\begin{array}{l}\text { Crystolegia } \\
\text { Grandiflora }\end{array}$ & Isopolar & Perprolate & V. L. & tricolpate & Lo & $\begin{array}{c}\text { Tectate } \\
\text { punctate }\end{array}$ & Moderare \\
\hline 12 & $\begin{array}{l}\text { Jacaranda } \\
\text { Mimosifolia }\end{array}$ & Heteropolar & Prolate & M. & tricolpate & --- & $\begin{array}{l}\text { Tectate } \\
\text { punctate }\end{array}$ & High \\
\hline 13 & Tecoma Stans & Isopolar & Prolate & M. & tricolporoidate & --- & Psilate & Moderare \\
\hline 14 & $\begin{array}{l}\text { Tecomaria } \\
\text { Capensis }\end{array}$ & Isopolar & Prolate & M. & tricolpate & Lo. & $\begin{array}{c}\text { Tectate } \\
\text { microretic }\end{array}$ & Moderare \\
\hline 15 & $\begin{array}{l}\text { Cestrum } \\
\text { Noctura }\end{array}$ & Isopolar & Perprolate & V.L. & tricolpate & --- & $\begin{array}{c}\text { Tectate } \\
\text { microretic }\end{array}$ & High \\
\hline 16 & Datura Inoxia & Isopolar & Spheroidal & M. & tricolporate & --- & Tectate striate & High \\
\hline
\end{tabular}

Abbreviations: $S=$ small less than $20 \mu \mathrm{m}, \mathrm{M}=$ =medium from $21-40 \mu \mathrm{m}, \mathrm{L} .=$ large from $41-75 \mu \mathrm{m}, \mathrm{V} . \mathrm{L} .=$ very large exceed $75 \mu \mathrm{m}$; Ora pos.=Ora position, Cir.=Circular, La.= Lalongate, Lo. =Lolongate; ExineOrn. = Exine ornamentation.

The morphological characters of the studied pollen taxa are summarized in Table 2 and illustrated in the (photo 22-47). While the element contents are mentioned in Table 3. The pollen grains of all the taxa share some characters as being generally radially symmetrical isopolar or apolar, usually dispersed as monad, except
Acacia tortilis pollens dispersed as polyads. Summary descriptions of the studied pollen grains are given below and in Table 2. The protein content was estimated quantitatively by the degree of activity with the stain. 


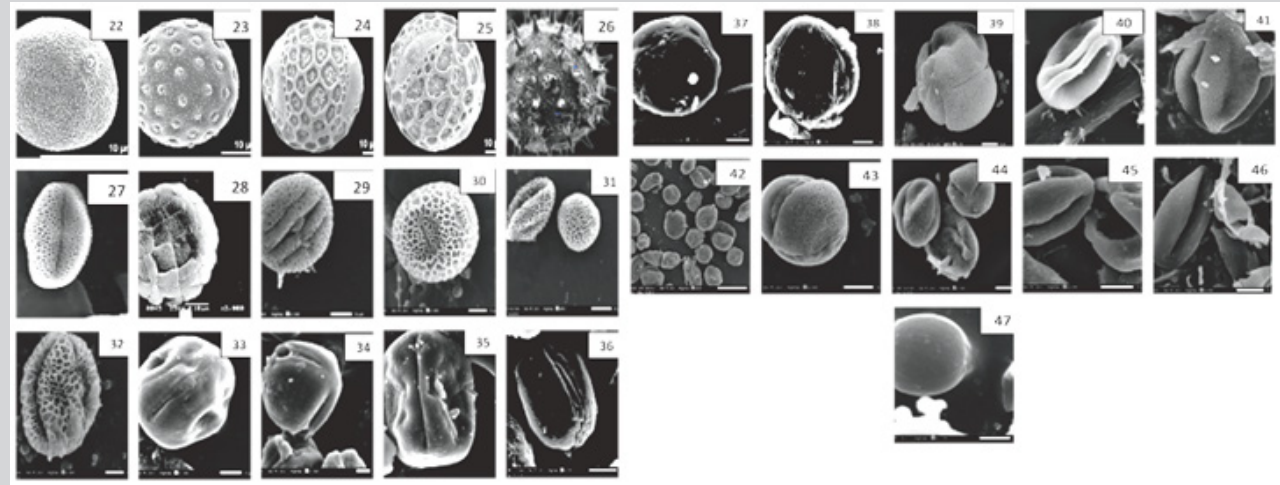

Photo 22-47: SEM Photographs of the studied taxa (Bar= $10 \mu \mathrm{m})$.

22. Utrica Urens, 23. Chenopodium Album, 24. Delonixregia, 25. Cassia javanica, 26. Acacia tortilis, 27. Malvaviscus Arboreus, 28. Croton cotinifolia, 29. Tamarixnilotica, 30,31 \&32. Carissa macrocarpa, 33\& 34. Catharanthus Roseus, 35. Crystostegia Grandiflora, 36,37\&38. Jacaranda Mimosifolia, 39,40\&41. Tecoma Stans, 42,43\&44. Tecomariacapensis,

45\&46. Cestrum Nocturnum, 47. Datura Inoxia

Table 3: Element composition in the Pollen grains of the studied taxa as shown by X-ray analyses.

\begin{tabular}{|c|c|c|c|c|c|c|c|c|c|c|c|c|c|c|c|}
\hline \multirow{2}{*}{ axa } & \multicolumn{15}{|c|}{$\%$ of the Mass of Investigated Elements } \\
\hline & $\mathbf{C}$ & $\mathbf{N}$ & $\mathbf{0}$ & $\mathrm{Na}$ & Mg & Al & $\mathbf{S i}$ & $\mathbf{P}$ & $\mathbf{s}$ & $\mathbf{C l}$ & $\mathbf{K}$ & $\mathbf{C a}$ & Fe & $\mathbf{C u}$ & $\mathbf{Z n}$ \\
\hline \multirow{2}{*}{ Itica Urens } & $35 \pm$ & $1.28 \pm$ & $41.01 \pm$ & $0.33 \pm$ & $5 \pm$ & $0.23 \pm$ & $37 \pm$ & $0.02 \pm$ & $16 \pm$ & $0.07 \pm$ & $46 \pm$ & $1.99 \pm$ & $.09 \pm$ & $.38 \pm$ & $0.09 \pm$ \\
\hline & 18 & 0.18 & 0.38 & 0.03 & 0.02 & & 02 & 0.01 & 01 & 0.01 & 0.03 & .05 & 0.02 & 0.05 & 0.03 \\
\hline \multirow{2}{*}{$\begin{array}{l}\text { Chenopodium } \\
\text { album }\end{array}$} & $55.52 \pm$ & $3.42 \pm$ & $37.28 \pm$ & $0.30 \pm$ & $0.34 \pm$ & $11 \pm$ & $.07 \pm$ & $0.44 \pm$ & $0.23 \pm$ & $0.62 \pm$ & $1.12 \pm$ & $0.06 \pm$ & $0.08 \pm$ & $.34 \pm$ & $.07 \pm$ \\
\hline & 0.19 & 0.22 & 0.38 & 0.03 & 0.02 & 0.02 & 0.01 & 0.02 & 0.02 & 0.03 & 0.04 & 0.02 & 0.02 & 0.04 & 0.03 \\
\hline \multirow{2}{*}{ lonix regia } & $60.16 \pm$ & $2.11 \pm$ & $35.26 \pm$ & $0.08 \pm$ & $0.05 \pm$ & $0.20 \pm$ & $19 \pm$ & $0.22 \pm$ & $14 \pm$ & $0.13 \pm$ & $65 \pm$ & $0.28 \pm$ & $0.04 \pm$ & $0.26 \pm$ & $0.25 \pm$ \\
\hline & 0.2 & 0.22 & 39 & 0.02 & 0 & 2 & 0.02 & 0.02 & 0.01 & 0.01 & 0.03 & 0.02 & 0.02 & 0.05 & 0.05 \\
\hline \multirow{2}{*}{ Cassia javanica } & $62.85 \pm$ & & $34.24 \pm$ & $0.11 \pm$ & & $0.08 \pm$ & & $0.48 \pm$ & $0.22 \pm$ & $0.05 \pm$ & $0.70 \pm$ & $0.38 \pm$ & $0.12 \pm$ & $0.39 \pm$ & $0.39 \pm$ \\
\hline & 0.23 & & 0.45 & 0.03 & & 0.02 & & 0.03 & 0.02 & 0.01 & 0 & 0.03 & 0.03 & 0.06 & 0.06 \\
\hline \multirow{2}{*}{ Acacia tortilis } & $59.59 \pm$ & $11.97 \pm$ & $24.77 \pm$ & $0.07 \pm$ & $0.03 \pm$ & $0.11 \pm$ & $0.42 \pm$ & $0.03 \pm$ & & $1.99 \pm$ & $0.02 \pm$ & $0.22 \pm$ & $0.06 \pm$ & $0.48 \pm$ & $0.24 \pm$ \\
\hline & 0.28 & 0.51 & 0.49 & 0.03 & 0.02 & 0.02 & 0.0 & 0.02 & & 0.06 & 0.02 & 0.03 & 0.02 & 0.07 & 0.07 \\
\hline \multirow{2}{*}{$\begin{array}{l}\text { Malviscus } \\
\text { arboreus }\end{array}$} & $58.47 \pm$ & $0.80 \pm$ & $38.35 \pm$ & $0.10 \pm$ & $0.08 \pm$ & $0.11 \pm$ & $0.08 \pm$ & $0.20 \pm$ & $0.09 \pm$ & $0.12 \pm$ & $0.49 \pm$ & $0.04 \pm$ & $0.04 \pm$ & $0.24 \pm$ & $0.20 \pm$ \\
\hline & 0.26 & 0.25 & 0.52 & 0.03 & 0.02 & 0.02 & 0.02 & 0.02 & 0.02 & 0.02 & 0.04 & 0.02 & 0.02 & 0.05 & 0.06 \\
\hline \multirow{2}{*}{ Croton cotinifolia } & $60.86 \pm$ & $2.75 \pm$ & $33.03 \pm$ & $0.03 \pm$ & $0.37 \pm$ & $0.02 \pm$ & $0.06 \pm$ & $0.66 \pm$ & $0.25 \pm$ & $0.36 \pm$ & $0.65 \pm$ & $0.41 \pm$ & $0.03 \pm$ & $0.27 \pm$ & $26 \pm$ \\
\hline & 0.24 & 0.28 & 46 & 0. & . & 0.02 & & 0.03 & 0.02 & 0.03 & 04 & 3 & .02 & .05 & 0.06 \\
\hline \multirow{2}{*}{ Tamarix nilotica } & $55.38 \pm$ & $3.61 \pm$ & $37.79 \pm$ & $0.67 \pm$ & $0.29 \pm$ & $0.01 \pm$ & & $0.30 \pm$ & $0.39 \pm$ & $0.64 \pm$ & 0.23 & $0.17 \pm$ & $0.04 \pm$ & $0.22 \pm$ & $0.26 \pm$ \\
\hline & 0.18 & 0.2 & 0.34 & 0.04 & 0.02 & 0.01 & & 0.02 & 0.02 & 0.02 & \pm 0.02 & 0.02 & 0.01 & 0.03 & 0.04 \\
\hline \multirow{2}{*}{ Carissa macrocarpa } & $58.84 \pm$ & $2.22 \pm$ & $36.62 \pm$ & $0.06 \pm$ & $0.14 \pm$ & $0.05 \pm$ & $0.05 \pm$ & 0.28 & $0.17 \pm$ & \multirow{2}{*}{0} & $0.80 \pm$ & $0.33 \pm$ & $0.04 \pm$ & $0.28 \pm$ & $0.13 \pm$ \\
\hline & 0.19 & 0.21 & 0.39 & 0.02 & 0.02 & 0.01 & - & \pm 0.02 & 0.01 & & 0.03 & 0.0 & רחת & 0.04 & 0.04 \\
\hline \multirow{2}{*}{ Catharan-thusroseus } & $53.07 \pm$ & $2.79 \pm$ & 41.02 & $0.03 \pm$ & $0.07 \pm$ & $0.00 \pm$ & 0.0 & $0.24 \pm$ & $0.14 \pm$ & $0.46 \pm$ & $1.36 \pm$ & $0.25 \pm$ & & $.25 \pm$ & $0.22 \pm$ \\
\hline & 0.19 & 0.21 & \pm 0.40 & 0.02 & 0.02 & 0.02 & 0.01 & 0.02 & 0.01 & 0.02 & 0.04 & 0.02 & & 0.04 & 0.05 \\
\hline \multirow{2}{*}{$\begin{array}{l}\text { Crystolegia } \\
\text { grandiflora }\end{array}$} & $52.16 \pm$ & $1.47 \pm$ & $38.54 \pm$ & $1.66 \pm$ & $0.15 \pm$ & $0.10 \pm$ & $0.28 \pm$ & $0.56 \pm$ & $0.14 \pm$ & $1.80 \pm$ & $1.07 \pm$ & $1.07 \pm$ & $0.19 \pm$ & $0.43 \pm$ & $0.40 \pm$ \\
\hline & 6 & 2 & 17 & 007 & (202 & 0 & 0.03 & 0.03 & 02 & 006 & 005 & O 0 & 002 & 0.06 & 0.07 \\
\hline \multirow{2}{*}{$\begin{array}{l}\text { Jacaranda } \\
\text { mimosifolia }\end{array}$} & $57.86 \pm$ & $2.28 \pm$ & $35.97 \pm$ & $35.97 \pm$ & $0.20 \pm$ & 0.0 & 0. & $0.61 \pm$ & $0.38 \pm$ & $0.02 \pm$ & $1.29 \pm$ & $0.45 \pm$ & & $.49 \pm$ & $0.06 \pm$ \\
\hline & 0.3 & 0.33 & 0.6 & 0.6 & 0.03 & 0.03 & 0.03 & 0.04 & 0.03 & 0.02 & 0.07 & 0.05 & & 0.09 & 0.07 \\
\hline \multirow{2}{*}{ Tecomastans } & $61.38 \pm$ & & $36.84 \pm$ & $0.06 \pm$ & $0.12 \pm$ & $0.06 \pm$ & $0.06 \pm$ & 0 & $0.12 \pm$ & $0.08 \pm$ & $0.36 \pm$ & $0.51 \pm$ & 0 & $0.25 \pm$ & $0.16 \pm$ \\
\hline & 0.2 & & 0.41 & 0.02 & 0.02 & 0.02 & 0.02 & 0 & 0.01 & 0.01 & 0.03 & 0.03 & 0 & 0.04 & 0.04 \\
\hline & $54.20 \pm$ & 0 & 40.53 & 0 & $0.35 \pm$ & 0 & $0.06 \pm$ & $0.59 \pm$ & $0.49 \pm$ & $0.45 \pm$ & $2.33 \pm$ & $0.27 \pm$ & $0.02 \pm$ & $0.52 \pm$ & $0.20 \pm$ \\
\hline Tecomanta capensis & 0.27 & 0 & \pm 0.54 & 0 & 0.04 & 0 & 0.02 & 0.04 & 0.03 & 0.03 & 0.08 & 0.04 & 0.02 & 0.08 & 0 \\
\hline & $59.79 \pm$ & $1.54 \pm$ & $35.37 \pm$ & 0 & $0.17 \pm$ & $0.07 \pm$ & $0.35 \pm$ & $0.32 \pm$ & $0.28 \pm$ & $0.16 \pm$ & 0.84 & $0.34 \pm$ & $0.00 \pm$ & $0.37 \pm$ & $0.44 \pm$ \\
\hline & 0.22 & 0.22 & 0.43 & & 0.02 & 0.02 & 0.03 & 0.02 & 0.02 & 0.02 & \pm 0.40 & 0.03 & 0.02 & 0.05 & 0.06 \\
\hline & $55.9 \pm$ & $3.57 \pm$ & $38.52 \pm$ & $0.04 \pm$ & $0.11 \pm$ & 0 & $012 \pm$ & $0.29 \pm$ & $0.22 \pm$ & $0.04 \pm$ & $1.20 \pm$ & $0.20 \pm$ & $0.08 \pm$ & $0.35 \pm$ & $0.18 \pm$ \\
\hline $\mathrm{Dc}$ & 0.28 & 0.35 & 0.6 & 0.03 & 0.03 & 0 & 0.03 & 0.03 & 0.03 & 0.02 & 0.06 & 0.03 & 0.03 & 0.07 & 6 \\
\hline
\end{tabular}


1. Utrica urens pollen grains apolar,oblate-spheroidal to spheroida, small from 12.2-15.9 $\mu \mathrm{m}$. The grains have from two to four circular pores with elevated lips, exine tectate granulate (Photo 22). The pollen has intense protein concentrations. The protein content is very high.

2. Chenopodium album pollen grains apolar, spheroidal medium in size from 27.5 to $29.2 \mu \mathrm{m}$., pantoporate with numerous circular pores covered with exinous verrucae, exinetectate granulate (Photo 23). The pollen has high protein concentrations.

3. Delonix regia pollen grains isopolar, prolatelarge in size from 50.6 to $55.7 \mu \mathrm{m}$. in length, prolatetricolporoidate. Colpi length about $24 \mu \mathrm{m}$. with rounded ends and finely reticulate membrane. Ora poorly developedlalongate,exine widely reticulate with granulate endexine (Photo 24).The pollen has weak protein concentrations.

4. Cassia javanica pollen grains isopolar, subprolate to prolate medium in size from 27.8-37.2 $\mu \mathrm{m}$ in length, tricolporoidate. Colpi length about $15 \mu \mathrm{m}$ with lolongateora, exine widely reticulate with granulate endexine (Photo 25). The pollen has Moderate protein concentrations.

5. Acacia tortilis pollen grains apolar, spheroidal large in size from 42.8 to $66.4 \mu \mathrm{m}$, multicolpate, exinetectate punctuate, sometimes with fine foveolae (Photo 26 ). The pollen has moderate protein concentrations.

6. Malvaviscus arboreus pollen grains apolar, spheroidal very large in sizefrom $148-167 \mu \mathrm{m}$, pantoporate with numerous distinct pores, from 1.8 to $2.5 \mu \mathrm{m}$, exine tectate spinulose (Photo 27). The pollen has moderate protein concentrations.

7. Croton cotonifolia pollen grains isopolar, prolate with medium size, P.A. from 38.5-46.8 $\mu \mathrm{m}$ tricolporate, with tectatereticulateexine (Photo 28). The pollen has high protein concentrations.

8. Tamarix nilotica pollen grains isopolar, prolate small in size P.A. from 12.62 to $17.26 \mu \mathrm{m}$, tricolpate with reticulate exine (Photo 29). The pollen has moderate protein concentrations.
9. Carissa macrocarpa pollen grains of two types. Type one apolar, spheroidal large from 53-75 $\mu \mathrm{m}$, tetracolpate with reticulate exine and type two isopolar, prolate large, P.A. 57.2-74.2 $\mu \mathrm{m}$, tricolporate with, lolongateora and reticulate exine (Photo 30-32). The pollen has high protein concentrations.

10. Catharanthus roseus pollen grains isopolar, subprolate medium size, P.A. from 42.6-51.2 $\mu \mathrm{m}$, tricolporate with lolongate plugged ora and tectate punctuate exine (Photos 33,34). The pollen has moderate protein concentrations.

11. Crystostegia grandiflora pollen grains isopolar, perprolate with very large size, P.A. from 76.8-112.6 $\mu$ m, tricolpate with tectate punctuate exine (Photo 35 ). The pollen has moderate protein concentrations.

12. Jaccaranda mimosifolia pollen grains heteropolar, prolate with medium size, P.A. from 38.2-46.7 $\mu \mathrm{m}$, tricolporoidate, colpi long with small, plugged lolongateora, exinepsilate (Photos 36-38). The pollen has high protein concentrations.

13. Tecoma stans pollen grains isopolar, prolate with medium size, P.A. from 38.2-46.7 $\mu \mathrm{m}$, tricolporoidate, colpi long with small, plugged lolongateora, exinetectatemicroreticulate (Photo 39-41). The pollen has moderate protein concentrations.

14. Tecomaria capensis pollen grains isopolar, prolate with medium size, P.A. from 55.4-72.9 $\mu \mathrm{m}$, tricolpate, colpi long and wide, syncolpate at one pole only, exinetectatemicroreticulate (Photo 4244). The pollen has high protein concentrations.

15. Cestrum nocturnum pollen grains isopolar, perprolate with large size, P.A. from76.2-82.7 $\mu \mathrm{m}$, tricolpate, colpi long and sunken, exinetectate striate (Photos 45,46 ). The pollen has high protein concentrations.

16. Datura inoxia pollen grains isopolar,spheroidal medium in size from 34.2 to $46.7 \mu$ mtricolporate with short colpiand lalongate small pores, exine tectate striate or punctate (Photo 47). The pollen has high protein concentrations.

\section{Element and Protein Contents}

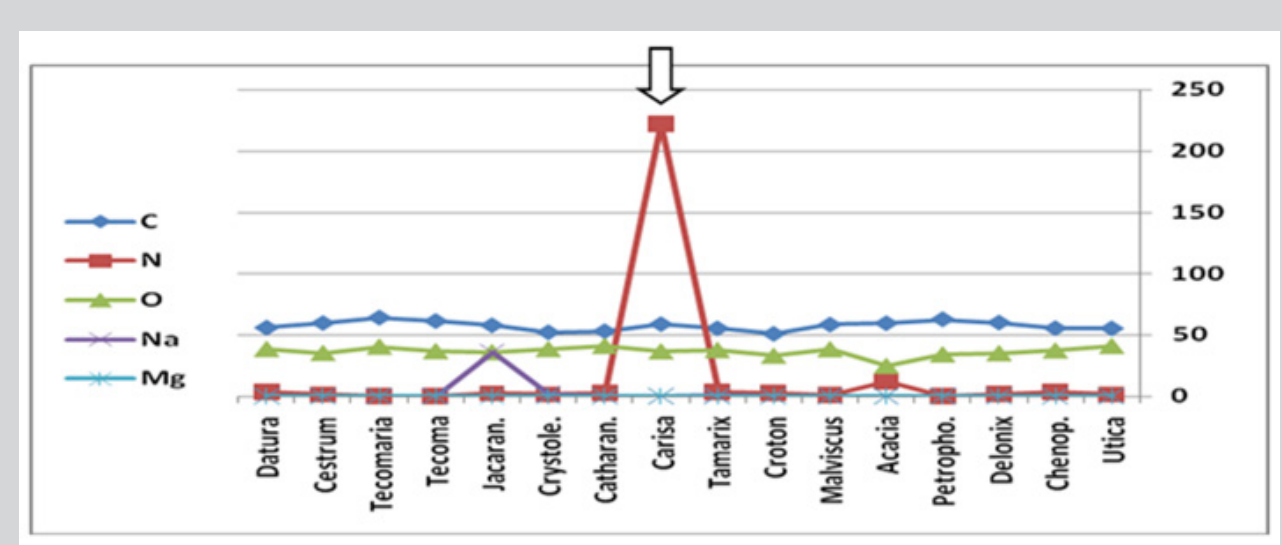

Figure 1: Illustrate the variations in the percentage of the different investigated elements in the pollen grains of the studied taxa.

Table 3 \& Figure 1-3, summarize and illustrate the percentage of the element compositions in the studied pollen grains. From the Table and Figure 1, we can find that the Carbon contents in all the studied taxa is considerably high, exceed $50 \%$, with the maximum percentage in Delonix regia, Cassia javanica, Croton cotinifolia and Tecoma stans where it exceeds $60 \%$. The Nitrogen contents are very low never exceed 3 to $4 \%$, and completely absent in both Tecoma stans and Tecomaria capensis, while it reaches 11.97 in Acacia bothUtrica urens and Catharanthus roseus. Sodium is very low in all the taxa, never exceed $2 \%$ and completely absent in both Tecomaria capensis and Cestrum noctura, but in Jacaranda mimosifolia it reaches $35.97 \%$. 
Magnesium, Aluminium, Silicon, Phosphorous, Sulphur, Chlore, Potasium, Calcium, Ferrous, Copper and Zinc (Figure 2,3) are all represent in very small amounts in all the studied taxa, with slight increase in Magnesium contents in Chenopodium album pollen grains. P slightly increased in Chenopodium album, Cassia javanica, Croton cotinifolia, Crystolagia grandiflora and Jaccaranda mimosifolia.

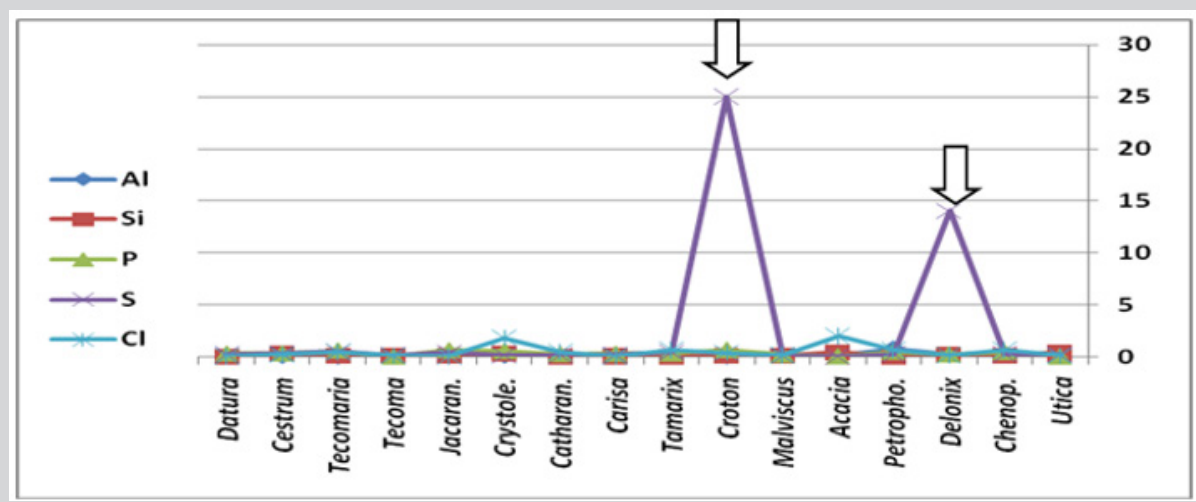

Figure 2: Illustrate the variations in the percentage of the different investigated elements in the pollen grains of the studied taxa.

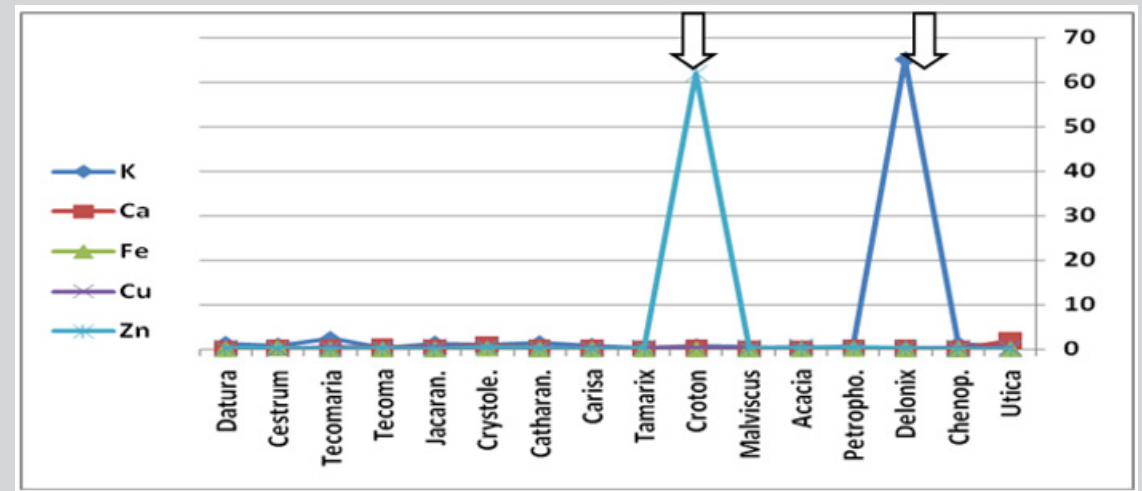

Figure 3: Illustrate the variations in the percentage of the different investigated elements in the pollen grains of the studied taxa.

In spite of the $\mathrm{S}$ contents are very low, never exceed $0.4 \%$, in all the pollen taxa, it jumps to $14 \%$ in Delonix regia. The same for the $\mathrm{K}$ contents which jump to $65 \%$ in that species. The $\mathrm{Cl}$ give slight increase in both Acacia tortilis and Crystolagia grandiflora, while Ca shows its greatest value in Crystolagia grandiflora.Fe is very low in all the studied taxa, while $\mathrm{Cu}$ increased slightly in Acacia tortilis, Tecomaria capensis and Jaccaranda mimosifolia. The Zn contents are very low in all the taxa except in Croton cotinifolia it reaches $26 \%$.

The protein contents have been estimated as the degree of staining and it was under four categories, dense in Utrica urens only, and weak in Delonix regia only, while the rest of the studied taxa have either moderate or high protein contents.

\section{DISCUSSION}

The process of pollination is a common event within higher plants. Plants are either pollinated by air or insects. Those pollinated by air are the main causes of allergy. Proteins and glycoproteins secreted by pollen grains after hydrations interact with the immune system of sensitive individuals causing symptoms of allergy. The pollen grains, when dispersed, are dehydrated and in contact with the stigma or the mucous membrane it rehydrated and stimulate the emergence of pollen tubes Buitink et al. [12]; Mariani et al. [13]. Blackley [14] performed some tests to document the effect of pollen grains on allergic symptoms since more than
60 years. Spieksma [15] reported more than 200 pollen grains, extracts of allergens for trees, grass, and weeds that are distributed by vendors worldwide. The size of the pollen grains considered from the important character in inducing allergy. Small pollen grains are easily dispersed by air and inhaled, while big size pollen grains prefer to be carried by insects or sort of dispersals. From the data obtained Utrica urens and Tamarix aphylla are the smallest pollen grains and these two species have been recorded as allergens by Mcinnes et al. [16]. The polarity, symmetry, shape and apertures are not important characters in inducing allergy, but the exine ornamentations may have role in pollination and meanwhile their density $t$ in the air.

Minerals play many important roles in regulating body chemistry. Toxic amounts of any nutrient will displace other vital nutrients and by doing so, result in various metabolic dysfunctions, including a wide variety of allergies. Chemical analysis of pellets containing pollen grains for the studied taxa was done to investigate the type of elements they contain; the results showed that all the pollen grains contain Carbon contents is considerably high, exceed $50 \%$, with the maximum percentage in Delonix regia, Cassia javanica, Croton cotinifolia and Tecoma stans where it exceed $60 \%$. This can be due to the amount of sugar released and the carbohydrate contents in the pollens. This excess Carbohydrates as starch and sugar are considered as antigen released subjects as mentioned by D`amato et al. [17]. 
Nitrogen and Sodium contents are very low never exceed 3 to $4 \%$, and completely absent in both Tecoma stans and Tecomaria capensis with the maximum content in Acacia and both Utrica urens and Catharanthus roseus in the former, while the Sodium contents was $2 \%$ or lower in all the taxa and completely absent in Tecomaria capensis and Cestrum noctura except in Jacaranda mimosifolia it reach $35.97 \%$. Meyer et al. [18] found that the deficiency in vitamin $\mathrm{D}, \mathrm{Zn}, \mathrm{Cu}, \mathrm{Ca}$ and other micronutrients is associated with different types of allergy in children. Accordingly, the low contents of some minerals in the pollen grains may be an additive factor in sensitive peoples, but we cannot consider it as the main cause of allergy. Here, Magnesium, Aluminium, Silicon, Phosphorous, Sulphur, Chlore, Potasium , Calcium, Ferrous, Copper and Zinc [Figure 1-3] are all represent in very small amounts in all the studied taxa, with slight increase in $\mathrm{Mg}$. and P. contents in Chenopodium album. P contents increased also in Cassia javanica, Croton cotinifolia, Crystolagia grandiflora and Jaccaranda mimosifolia. In spite of the S contents is very low, never exceed $0.4 \%$, in all the pollen taxa, it jumps to $14 \%$ in Delonix regia. The same for the $\mathrm{K}$ contents which jump to $65 \%$ in that species. The $\mathrm{Cl}$ gives slight increase in both Acacia tortilis and Crystolagia grandiflora, while Ca shows its greatest value in Crystolagia grandiflora. $\mathrm{Cu}$ increased slightly in Acacia tortilis, Tecomaria capensis and Jaccaranda mimosifolia. The Zn contents are very low in all the taxa except in Croton cotinifoliait reach $26 \%$. Stohs [19] studied a case of individuals allergic to sulfite and sulfonamides and became allergic to sulfate potassium and sulfur containing compounds. These results indicate that $S$ and $\mathrm{K}$ may induce allergic symptoms. Deficiencies in both calcium and magnesium in individuals are associated with tissue inflammation leading to increasing cell permeability and induce allergic symptoms. Dr. Victor Marchione, MD, Category: Health - March 9, 2011 announced that taking the three elements; Mg., Se and Zn can improve the immune system and banish allergy. Oleksyn et al. [20] found that the increase in the element composition in the pollen grains affect their functions and this increase is due to air pollution.

Thus, element contents and metal allergy have proved their effects on sensitive peoples (Uter et al., 2016). They found that there is cross reactivity between Nickel, Cobalt and Chromium especially to over 40 years old peoples in both sexes. The same has been proved by Uter et al. [21] by the addition of Aluminum to the sensitive elements. In our investigations, all the taxa are pollen cleared $\mathrm{Al}$. and with little amounts of all the heavy metals under analyses ( $\mathrm{Fe}, \mathrm{Cu}$ and $\mathrm{Zn}$ ).

Protein contents can play role in inducing allergic symptoms. Here we just estimate quantitatively the protein contents in the studied taxa. Each taxon has its specific proteins to make the stigma recognized the suitable pollen grains and to defense some pathogens. Rimmer et al. [22] indicated to the solubility of the pollen proteins in the aqueous medium of the mucous membrane after inhaling the pollen grains which cause allergy. Stewart [23] mentioned that plant families are grouped according to their sequence homology with the constitutive or inducible pathogenesis-related proteins (PR). They concluded that pollen PR members, whether trees or herbs, are usually minor allergens, in spite of being clinically important. Our data here revealed the presence of four categories of protein quantitative contents which are unrelated to either pollen characters or mineral contents. The only taxon with intense protein content is Utrica urens [24-30].

\section{CONCLUSION}

From this study, we conclude that not all the road trees are allergic. Allergic symptoms may be due to the inhaling of the excess pollen grains in the air which stimulate the baste cells to release the histamine and increase the IgE inside the body. As well as, allergy is not restricted to trees, shrubs or herbs but it depends on the amount of pollen grains in the air and the degree of air pollution and humidity which rehydrates the pollen to excrete its contents. Mineral contents are variable and depend on the carbohydrate, fats and protein contents within the different taxa. Protein type, not concentration, has allergic effect and this need specific analyses and studies. Finally, we recommend choosing the colored bisexual flowers (entomophilous pollination) and monoecious trees to be planted in the streets to avoid excess pollen grains in the air. Meanwhile we recommend avoiding over planting in the streets, parks and gardens and planted variations of taxa with bright colored flowers to increase the biodiversity and sustainability of the ecosystem. Plant Diversity is important way to alleviate this problem, minimize pollinosis and creates better urban wildlife areas.

\section{ACKNOWLEGMENT}

I would like to acknowledge Prof. Dr. Ahmed Kamel Hegazy, Plant Ecology and Environmental Sciences (Applied Ecology) Bot \& Micro..Dept. Cairo University, for his fruitful discussion which emerge the idea of this work.

\section{REFERENCES}

1. D’Amato G, Vitale C, De Martino A, Viegi G, Lanza M, et al. (2015) Effects on asthma and respiratory allergy of climate change and air pollution. Multidiscip Respir Med. 10: 39.

2. Fukuoka A, Matsushita $\mathrm{K}$, Morikawa $\mathrm{T}$, Takano $\mathrm{H}$, Yoshimoto $\mathrm{T}$ (2016) Diesel exhaust particles exacerbate allergic rhinitis in mice by disrupting the nasal epithelial barrier. Clin Exp Allergy 46(1): 142-152.

3. Saad SI (1963) On the terminology of pollen stratification. Pollen et spores 5(2): 451-454.

4. Prado N, Concepción De Linares, María L, Gamboa SP, Villalba M, et al. (2015) Pollensomes as natural vehicles for pollen allergens. J Immunol 195(2): 445-449.

5. Grote M, Vrtala S, Valenta R (1993) Monitoring of two allergens, Bet v I and profilin, in dry and rehydrated birch pollen by immunogold electron microscopy and immunoblotting. J Histochem Cytochem 41(5): 745750.

6. Emilson A, Berggren B, Svensson A, Takahashi Y, Scheynius A (1996) Localization of the major allergen Bet $\mathrm{v}$ I in birch pollen by confocal laser scanning microscopy. Grana 35(4): 199-204.

7. Geiner T, Wehner A, Schaab C, Cox J, Mann M (2012) Comparative proteomic analysis of eleven common cell lines reveals ubiquitous but varying expression of most proteins. Mol Cell Proteomics 11(3): M111.

8. Osborne N, Eggen B (2015) Pollen and asthma: impacts of anthropogenic climate change. Living with Environmental Change. LWEC, NERC, Swindon, UK.

9. Asam C, Hofer H, Wolf M, Aglas L, Wallne M, et al. (2015) Tree pollen allergens-an update from a molecular perspective. Allergy $70(10)$ 1201-1211.

10. Heinedy SZ (2011) Plant Atlas, the botanic garden (Alex). In Manshaet El Maaref, Galal Hezy et al., $1^{\text {st }}$ edn, Alexandria, Egypt.

11. Faegri K (1956) Recent trends in palynology. Bot Rev 22(9): 639-664.

12. Buitink J, Claessens MMAE, Hemminga MA, Hoekstra FA (1998) Influence of water content and temperature on molecular mobility and intracellularglasses in seeds and pollen. Plant Physiolol 118(2): 531541.

13. Mariani V, GillesS, Jakob T, Thiel M, Mueller MJ, Ring J (2007) Immunomodulatory mediators from pollen enhance the migratory capacity of dendritic cells and license them for Th2 attraction. J Immunol 178(12): 7623-7631 
14. Blackley CH (1959) Experimental Researches on theCauses and Nature of Catarrhusaestivus (Hayfeveror Hay-Asthma). Dawson's of Pall Mall, Tindall \& Cox, Baillière, London.

15. Spieksma FTM (1991) Regional European pollen calendars. In: D’Amato G, Spieksma FTM, Bonini S (eds.). Allergenic pollen and pollinosis in Europe. Oxford: Blackwell Sci Publishing, USA, pp. 49-65.

16. Mcinnes RN, Hemming D, Burgess P, Lyndsay D, Osborne NJ, et al. (2017) Mapping allergenic pollen vegetation in UK to study environmental exposure and human health. Science of Total Environment 599(600): 483-499.

17. D’Amato G, Cecchi L, Bonin S, Nunes C, Annesi MI, et al. (2007) Allergenic pollen and pollen allergy in Europe. Allergy 62(9): 976-990.

18. Meyer R, De Koker C, Dziubak R, Skrapac AK, Godwin H, et al. (2015) A practical approach to vitamin and mineral supplementation in food allergic children. Clin Transl Allergy 5:11.

19. Stohs S, Miller MJ (2014) A case study involving allergic reactions to sulfur-containing compounds including sulfite, taurine, acesulfame potassium and sulfomnides. Food Chem Toxicol 63: 240-243.

20. Oleksyn J, Reich PB, Karolewski P, Tjoelker MG, Chalupka W (1999) Nutritional status of pollen and needles of diverse Pinus sylvestris populations grown at sites with contrasting pollution. Water, Air and Soil Pollution 110(1-2): 195-212.

21. Uter W, Larese FF, Rui F, Balato A, Wilkinson M, et al. (2016) ESSCA results with nickel, cobalt and chromium, 2009-2012. Contact Dermat 75(2): 117-121.
22. Rimmer I, Santos C, Yli-Panula E, Noronha V, Viander M (2015) Clinical and laboratory studies of the fate of intranasal allergen. PLoS One 10(5): e0127477.

23. Stewart GA, Robinson C (2017) Chapter 4, Indoor and outdoor allergens and pollutants. Middleton`s Allergy Essentials: 73-116.

24. (1987) Analytical Research Laboratories (ARL) Inc Nutritional causes of allergies 2225 W Alice Avenue Phoenix, Arizona 85021, USA.

25. Bousquet J, Khaltaev N, Cruz AA, Denburg J, Fokkens WJ, et al. (2008) Allergic rhinitis and its impact on asthma. Allergy 63(86): 8-160.

26. Mazia D, Brewer PA, Alfert M (1953) The cytochemical staining and measurement of proteins with mercuric bromophenol blue. Biol Bull 104(1): 57-67.

27. Songnuan W (2013) Wind-pollination and the roles of pollen allergenic proteins. Asian Pac J Allergy Immunol 31(4): 261-270.

28. The angiosperm phylogeny group (APG) (2009) An update of the angiosperm phylogeny group classification for the orders and families of flowering plants. Bot J Linn Soc 161: 105-121.

29. Ulter W, Werfel T, White IR, Johansen JD (2018) Contact allergy: A review of current problems from a clinical perspective. Int J Environ Res Public Health 15(6): 1108.

30. Wolters-Arts M, Van der Weerd L, Van Aelst AC, Van der Weerd J, Van $\mathrm{AH}$ et al. (2002) Water-conducting properties of lipids during pollen hydration. Plant Cell Environ 25: 513-519. 